\title{
A RESEARCH ABOUT REVENUE MANAGEMENT AWARENESS AND APPLICATIONS IN TURKISH HOTEL INDUSTRY
}

\author{
Raif Parlakkaya ${ }^{1}$ \\ Halil Akmeşe ${ }^{2}$ \\ Ersin Arıkan ${ }^{3}$
}

\begin{abstract}
Fierce competition and changing business context are leading the business enterprises to develop and apply new tools and methods in order to survive or attain growth targets. In this regard revenue management and its application methods are gaining more importance each day. Revenue management, which might be defined as the art of maximizing revenue and profit indirectly by means of selling a service which is subject to time and capacity restrictions in the short run. Major aim of this study is to reveal the awareness level and applications of hotels which might be considered as the major and most institutional players of tourism industry. Relevant headlines such as a short history of revenue management, its components, advantages and disadvantages of revenue management applications, barriers in front of the revenue management process are mentioned within the context of study. In order to state the current situation in Turkey, a reliable sample of hotels ( 30 hotels of five and four stars) from Ankara, capital city of Turkey, was chosen and these hotels were subjected to a short questionnaire which is designed on previous studies about revenue management. Based on the findings of research it might be claimed that the majority of participants are aware of revenue management and are using various tools with differentiating degrees in order to maximize their revenue or attain their revenue targets.
\end{abstract}

Keywords: Revenue management, hotel revenue management, revenue management applications, revenue maximization

\section{INTRODUCTION}

Revenue management efforts might be based on demand and supply concepts within the context of free market economy. Every kind of market might be segmented and all the segments react in differentiating levels to any price change. As part of the service industry hotels and other accommodation facilities intensely use revenue management in order to maximize their revenue. Due to the perishable nature of services, because they are limited with time, revenue management gains its highest value within the managerial tools of service enterprises. However, revenue management as a tool needs to be treated delicately. Otherwise the results might be unexpected due to the parameters which need to be incorporated into the models developed for attaining revenue targets. Additionally these parameters should be measured and monitored continuously and consistently for better results. It might be claimed that previous studies on revenue management are on the focus of researchers and are evaluated as instructions by managers. Literature review constitutes the first part of this study.

\footnotetext{
${ }^{1}$ Professor, Departmant of Business Management, Faculty of Social and Human Sciences, Necmettin Erbakan University, Konya, Turkey.

${ }^{2}$ Assistant Professor, Departmant of Tourism Management, Faculty of Tourism, Necmettin Erbakan University, Konya, Turkey.

${ }^{3}$ Phd Student, Departmant of Tourism Management, Institute of Social Sciences, Necmettin Erbakan University, Konya, Turkey.
} 


\section{LITERATURE}

Revenue management is described as the price strategies and information systems applications that assign the right capacity to right customer at the right location on the right time (Kimes, 2000: 121). (Donaghy, 1995) described revenue management as a technical approach that aims to increase net revenue of estimated usable room capacity that has been determined based on the best rate and assigned to varying market segments.

In other words, revenue management is the adjustment of prices based on estimated demand levels and this is applied so that price-sensitive customers can decide to buy during off peak times and non-sensitive customers to price can decide to buy during on peak times (Kimes, 2000: 121).

Revenue management applications focus on three fundamental demand-management decisions that include structural decisions, price decisions and quantity decisions. Primarily structural decisions focus on which sales format is going to be utilized, which market segmentation or differentiation mechanism will be adopted and how products will be grouped. Price decisions include; how prices are going to be set, how different product categories are going to be priced, and how prices will change within a time frame. Finally, quantity decisions focus on how much of a capacity to allocate to different market segments in regards to accepting or rejecting a demand for a purchase, when the product will be withdrawn from market, and when it will be back on the market (Tan, 2012: 1).

\section{History of Revenue Management}

Revenue management concept first appeared in airline industry of United States in late 1970s with liberalization movement. Peoples Express (an airline company) was established with this liberalization aiming to fly passengers with less cost than other airline companies (Unurlu, 2010: 56). Big firms like American Airlines and United Airlines decided to compete with Peoples Express and started selling a low amount of seats for a cheaper price and other seats with high price tags. In this way they were expecting to carry pricesensitive passengers of Peoples Express along with other high-cost paying customers. At the end, customers of Peoples Express decided to use big airlines and after certain period of time Peoples Express filed for bankruptcy (Jerenz, 2008: 8). President of Peoples Express Donald Burr then admitted that most of problems they have faced were due to lack of revenue management (Hacioglu, 2011: 7).

Hotel businesses started using revenue management applications in midst of 1980s. Orkin focused on revenue statistics in his work about revenue management in 1988. Revenue statistics were calculated by dividing average room price by maximum room price and multiplying the result with occupancy rate. Most important point of this study is that instead of focusing on high occupancy rate or high average room rate managers should focus on maximum revenue (Kimes, 1989: 15).

Revenue management is vastly used in the airline and hotel industry. Other than these industries, railway transportation, cruise tourism, health services, electricity distribution, car rental, radio-tv commercials, entertainment, publishing and telecommunication businesses also practice revenue management applications successfully (Harris andPinder, 1995: 299). Along with fundamental principles that can be applied in different sectors easily, appropriate revenue management systems should be formed for each sector that embraces these sectors' characteristics and dynamics. For instance, a strategy used for 
airlines industry may not provide solutions for hotel and restaurant industry (Ivanov, 2014: 8).

\section{Elements of Revenue Management}

In order to develop a better understanding and a complete knowledge of revenue management constituents and important aspects of revenue management might be addressed. Following sub sections are of great importance regarding to revenue management and its expected results when applied.

\section{Demand and reservation features}

Revenue management helps for future estimations in times of high and low demands (LeeRoss and Johns, 1997: 67). Alongside with reservation status, being able to do demand forecasts efficiently helps businesses in decisions regarding getting reservations. Within this context, there are three different demand forecasting methods utilized by accommodation enterprises. These are occupancy rate forecasts, revenue based forecasts, and demand based forecasts (Buckhiester, 2011: 99-103):

Occupancy Rate Focused Forecasts: This forecasting method used in accommodation firms which generally have an operational structure. This forecasting model provides limited information and it is used for short terms. It provides information to the accommodation firm within a time frame regarding to how many rooms will be occupied, how many customers will accommodate along with groups and touristic tours information. Based on an analysis focusing on its structure; it helps other branches of the hotel on taskplanning but it is not very useful in the planning of revenues.

Revenue Based Forecasts: Another demand forecasting model utilized by accommodation firms is revenue based forecast model with its financial structure. This forecasting type focuses on occupancy rate, average rate and revenue for the upcoming months and provides knowledge to the management. In other words, it leads management in the areas of renting, purchasing, and cash flow necessities in a monthly manner.

Demand Based Forecasts:As a strategic demand forecasting approach, demand based forecast is a method that brings together information about previous information, reservation speed, marketing efforts and current room capacity of the market and then decisions are made based on this knowledge. Revenue managers with a developedknowledge about revenue management often apply this method while determining sales policies.

\section{Pricing}

Revenue management has two parts. First one is rooms management, capacity management in other words, and the other one is pricing. Resource usage as part of revenue management is the reserved room status based on current and future demands. Pricing is the best price that can be applied in different situations (Kimes, 1989: 15). Many people who do not have enough knowledge about revenue management think it is a method used by businesses which enables them to change prices constantly throughout the day. Actually revenue management is a type of price diversification (Kara, 2008: 20). In revenue management, the important point is to diversify price sensitive people with other groups that are willing to pay high prices (Wirtzve Kimes, 2007: 229). Airline firms 
change fare prices before the flight and throughout the day many times. Accommodation businesses should also adjust prices with a competitive understanding based on current demand and price effects on demand (Kimes, 1989: 18).

It is evident that most of approaches used by businesses to increase revenues are related to pricing applications. It can be said that decisions that will be made regarding pricing are important in regards to increasing and decreasing revenues. Based on his work about revenue management (Ivanov, 2014) specifies that "price diversification, dynamic pricing, low price guarantee" practices are directly related with pricing, and capacity management, excess reservation, room suitability guarantee and length of stay control practices are nonpricing practices.

\section{Information Systems}

Revenue management system can attain success based on the level it benefits from other information technology systems efficiently. If the system does not have integration, same information might have been entered into system more than once. Preventing this problem or resolving such matters reveals the importance of people in the area of revenue management. Although some firms are able to resolve this problem, many revenue management systems are not integrated with other information systems (Hacioğlu, 2011: 11). As computer-based information technology gets integrated with revenue management, revenue management is going to be able to be helpful to hotel managers in regards to selling varying customer groups rooms with diversified pricing and maximizing income (Choi and Cho, 2000: 18). In other words, information technologies and systems help ease the process of utilizing revenue management in the sector of accommodation (Jauncey, Mitchell and Slamet, 1995: 24).

\section{Overbooking Policy}

Efficiently using capacity is important in revenue management. Overbooking policy is practiced in the service sector in order to prevent non-usage of capacity due to cancellations and no-shows. As a result, reservation cancellations and no-shows cause revenue losses (Sfodera, 2006: 69). Overbooking is determined carefully by analyzing capacity and demand. It might be said that overbooking is practiced between 5 and $10 \%$ of total capacity within airline and accommodation businesses (Harris and Pinder, 1995: 303).

\section{Barriers in front of Revenue Management}

Revenue management is a strategic system especially for service sector in maximizing revenues and increasing profits. For this reason more firms start adopting it every day. It is important to use revenue management applications successfully for every business but there can be barriers in successfully applying revenue management. Based on his research about hotels in China, ( $\mathrm{Li}, 2011)$ describes barriers in front of revenue management as follows:

- Limited knowledge about revenue management: Most of hotel managers do not possess knowledge about revenue management. They perceive revenue management as price wars between competitors and price dumping policy instead of a strategy formed by the balance between supply and demand. 
- Limited information system:Information system within state owned hotels are not used efficiently. Instead of operating multi-function systems in an integrated format, each of them are operated in a single way. That's why state owned hotels possess information systems that lack rich technical knowledge and skills. And this causes the inability of accessing needed information for revenue management.

- Neglecting past information (knowledge):In order to have an efficient revenue management, there is a need to have demand forecasts based on historical data. Not recording historical data or not keeping them in the database cause problems in demand forecasting. And this causes the revenue management to be unsuccessful.

- Unreliability of the revenue management system:Revenue management system depends on forecasting and information technologies. Although revenue management system in some hotels have reached an advanced level by utilizing these tools, a lot of hotels still hasn't been able to form a reliable revenue management system.

\section{Advantages and Disadvantages of Revenue Management}

Capacity increase is not possible in the short-term due to limited capacity in hotel businesses and high costs of investments. For this reason it is not possible to sell rooms to more customers and increase revenue even if there is an increase in demand. At this point, revenue management system enables the business to increase prices in the case of increased demand and provides advantage to the firm by maximizing revenue and profit (Harris andPinder, 1995: 302). Another benefit of revenue management is to provide precaution against cancellations and no-shows by allowing overbooking.

Although revenue management system brings important benefits to firms that practice, it also has disadvantages. Businesses stay alive with customers. Customers may not have knowledge about the structure of this system. For this reason, they may prefer to stay away from firms that practice revenue management system thinking there can be problems with the process. And the business may lose customers. Another negativity can be faced on the employees of the business. This system brings workload and it bears risks associated with possible mistakes. And this has huge cost. That's why employees are skeptical about the system. Employees should be educated about the structure of the system and appropriate staff should be selected for the related tasks (Hacioğlu, 2011: 90).

\section{RESEARCH METHODOLOGY AND QUESTIONNAIRE}

A short questionnaire is designed based on the literature review and previous studies(Yousef, 2007) in order to come up with current status about revenue management among Turkish hotel enterprises. Research questionnaire is sent to 56 hotels ranked as four and five star hotels as listed on the Ankara branch official web site of Republic of Turkey Ministry of Tourism and Culture. Hotel managers are contacted by telephone and informed about the research in order to increase the participation rate and reliability of responses. Within the research context 30 responses out of 56 questionnaires are gathered by means of online applications. 


\section{FINDINGS}

Exploratory status of this study required gathering information about the demographic features of participating enterprises. Question 1 is designed in order to reveal the star ranking profiles of participating hotels. As it is summarized in Tab. 1, 57\% of the hotels are 4 star hotels and $43 \%$ are 5 star hotels. Additionally all the responses gathered belong to city hotels which might be considered within the group of business hotels instead of leisure hotels or resorts.

Tab. 1: Hotel status regarding to their star rankings

\begin{tabular}{|l|l|l|}
\hline Star Rankings of Participants & Frequency (n) & Percentage (\%) \\
\hline 4 star hotels & 17 & 57 \\
\hline 5 star hotels & 13 & 43 \\
\hline
\end{tabular}

As it is a known fact that the most important basis for revenue management has been the capacity, capacity usage in other words. Tab. 2 depicts the capacities of participating hotels based on a 50 room capacity interval. Nearly half of the hotels (except two hotels with total rooms up to 50 which represent $2 \%$ of respondents), approximately $43 \%$ of the respondents, reported that they have rooms between $51-100.30 \%$ of the other half represents the hotels with a room capacity of more than 150 rooms and $20 \%$ with a capacity of rooms between 101 and 150 . It might be said that the general capacity status of participating hotels are eligible for revenue management applications.

Tab. 2: Total number of rooms

\begin{tabular}{|l|l|l|}
\hline Number of rooms & Frequency (n) & Percentage (\%) \\
\hline $1-50$ & 2 & 7 \\
\hline $51-100$ & 13 & 43 \\
\hline $101-150$ & 6 & 20 \\
\hline 150 and more & 9 & 30 \\
\hline
\end{tabular}

Tab. 3 summarizes the type of proprietorship status of participating hotels. Two third of the participating hotels, $67 \%-20$ hotels, seem to be independent hotels while the rest of participants, $33 \%-10$ hotels, belong to a hotel chain proprietorship. Findings regarding to the proprietorship status of participating hotels revealed that regardless of their proprietorships, majority of the hotels are interested in revenue management and its applications. 
Tab. 3: Type of proprietorship

\begin{tabular}{|l|l|l|}
\hline & Frequency (n) & Percentage (\%) \\
\hline Chain hotel & 10 & 33 \\
\hline Independent hotel & 20 & 67 \\
\hline
\end{tabular}

Tab. 4 depicts the findings about awareness levels of participants. Three fourth of the participants, $73 \%$ - 22 hotels, reported that they are aware of the revenue management on a scale of moderately and extremely. Eight of the participants, $27 \%$ of the total, reported that they are slightly aware of the concept and two participants reported that they are unaware of revenue management. Findings reveled that majority of the participants are aware of revenue management and its applications.

Tab. 4: Degree of awareness about revenue management and its applications

\begin{tabular}{|l|l|l|}
\hline & Frequency (n) & Percentage (\%) \\
\hline Not at all & 2 & 7 \\
\hline Slightly & 6 & 20 \\
\hline Moderately & 2 & 7 \\
\hline More than moderately & 15 & 50 \\
\hline Extremely & 5 & 16 \\
\hline
\end{tabular}

Tab. 5 provides data about information sources of hotel managers regarding to revenue management. Findings revealed that the most important source of information for one third of the respondents, representing $33 \%$ of the total, about revenue management and its applications is educational programs arranged by different sources such as nongovernmental organizations. Copycat applications gathered by industrial relations constitute one fourth of general information resources representing $27 \%$. Books, journals and articles - other resources and courses constitute nearly the half of information resources respectively ranging from $17 \%$ to $13 \%$ and $10 \%$.

Tab. 5: Information resources about revenue management

\begin{tabular}{|l|l|l|}
\hline & Frequency (n) & Percentage (\%) \\
\hline Courses & 3 & 10 \\
\hline Educational programs & 10 & 33 \\
\hline Books, journals and articles & 5 & 17 \\
\hline Applications & 8 & 27 \\
\hline Other & 4 & 13 \\
\hline
\end{tabular}


As it is shown in Tab. 6, responses revealed that more than half of the participants, $57 \%$ 17 hotels, are willing to learn revenue management and its applications while the rest seems to be unwilling. It was found that one fourth of the respondents was unaware or insufficiently aware of revenue management and its applications, 27\% - 8 hotels, and was shown in Tab. 4. This might be interpreted that participants who are unaware of revenue management or have little knowledge about its applications are indifferent or unwilling regarding to the implementation of revenue management.

Tab. 6: Willingness to learn revenue management

\begin{tabular}{|l|l|l|}
\hline & Frequency (n) & Percentage (\%) \\
\hline Yes & 17 & 57 \\
\hline No & 13 & 43 \\
\hline
\end{tabular}

Tab. 7 summarizes the application status of revenue management by participating hotels. As it is apparent, responses shown below and responses shown in Tab. 4 are overlapping and findings of the research prove that higher degree of awareness about revenue management result in higher degree of applications about revenue management. It might be said that majority of the hotels are aware of the revenue management concept and they are applying variety of methods within the scope of their knowledge and interest.

Tab. 7: Revenue management applications within the organization

\begin{tabular}{|l|l|l|}
\hline & Frequency (n) & Percentage (\%) \\
\hline Yes & 20 & 67 \\
\hline No & 10 & 33 \\
\hline
\end{tabular}

Regarding to the duration of revenue management applications within the organization responses summarized in Tab. 8 revealed that a small majority, nearly 40 percent, is aware of the issue and apply in their hotels at most for 5 years. This might be due to the emerging nature of revenue management issue in Turkey, especially in hotel industry. $13 \%$ of the participants responded that they are using revenue management applications between 5-10 years and 17\% responded that they are using revenue management applications more than 10 years. It is apparent that revenue management and its applications are emerging issues within Turkish hotel industry when it is compared to the origination of this issue in 1980s.

Tab. 8: Timeframe for revenue management applications within the organization

\begin{tabular}{|l|l|l|}
\hline & Frequency (n) & Percentage (\%) \\
\hline Less than 5 years & 11 & 37 \\
\hline 5 to 10 years & 4 & 13 \\
\hline More than 10 years & 5 & 17 \\
\hline No idea & 10 & 33 \\
\hline
\end{tabular}


Tab. 9 summarizes the frequency of revenue management applications referred within the organization. Half of the participants reported that revenue management and its applications are used frequently within their organization. Approximately $15 \%$ reported that they used revenue management rarely or moderately. On the other hand one third of the participants did not respond to this question. This might be due to the involvement degrees of participants to the revenue management applications.

Tab. 9: Level of revenue management applications within the organization

\begin{tabular}{|l|l|l|}
\hline & Frequency (n) & Percentage (\%) \\
\hline Rare & 2 & 7 \\
\hline Moderate & 2 & 7 \\
\hline Frequent & 10 & 33 \\
\hline Frequent as a routine & 6 & 20 \\
\hline No idea & 10 & 33 \\
\hline
\end{tabular}

Regarding to the software assistance a small majority of participants responded that they are using software in order to obtain better results about revenue management. Nearly one fourth of the respondents $(27 \%)$ responded that they are managing the revenue management process on manual basis, meaning that they are using managerial information in order to make decisions about revenue management. Tab. 10 summarizes the results of question eleven regarding to the software assistance for revenue management.

Tab. 10: Software assistance for revenue management

\begin{tabular}{|l|l|l|}
\hline & Frequency (n) & Percentage (\%) \\
\hline Yes & 12 & 40 \\
\hline No & 8 & 27 \\
\hline No idea & 10 & 33 \\
\hline
\end{tabular}

Question 12 in the research questionnaire is designed to determine the commonly used revenue management tools by hotel enterprises subject to the research. Generally accepted in literature or commonly used techniques industrially are listed and respondents are expected to choose among these. As shown in Tab. 10 most widespread method used by hotels is stay length control. Following one is capacity management and overbooking or over contracting seems to be the third commonly used method. Research question is built on two dimensions; price and capacity. As it is listed in Tab. 11 dynamic pricing represents the price dimension of revenue management and might be considered as the essence of revenue management process and might be considered as the primary tool for revenue management (Talluri and Ryzin, 2004). The rest of revenue management tools listed in 
research question is related to the capacity dimension (Ivanov,2014). Findings revealed that capacity related revenue management tools are commonly used by participating hotels. Surprisingly dynamic pricing or other price related tools are not used in order to manipulate revenue. This might be due to the general economic conditions or competitive conditions.

Tab. 11: Commonly used revenue management tools

\begin{tabular}{|l|l|l|}
\hline & Frequency (n) & Percentage (\%) \\
\hline 1. Dynamic pricing & 0 & 0 \\
\hline 2. Capacity management & 8 & 26 \\
\hline 3. Overbooking or over contracting & 6 & 20 \\
\hline 4. Stay length control & 12 & 40 \\
\hline 5. Upselling & 4 & 13 \\
\hline 6. Optimal room allocation & 5 & 16 \\
\hline
\end{tabular}

Question 13 aims to determine the perceived effects of revenue management on the concluding evaluation information of enterprises such as efficiency as a whole, profitability, total costs and capacity usage. Tab. 12 demonstrates the findings below. Responses summarized below belong to the participants who are aware of revenue management and use revenue management tools and represent the two thirds of total respondents ( 20 out of 30 respondents). All respondents reported that they believed revenue management contributed to the efficiency of organization more than moderately or strongly by $60 \%$ and $40 \%$ respectively. Profitability is evaluated as to be affected by revenue management more than moderately or strongly by $45 \%$ and $55 \%$ respectively. Regarding to the cost reduction and capacity usage issues findings revealed that a small minority of the respondents, $15 \%$ and $5 \%$ respectively, believed that revenue management is slightly effective.

Tab. 12: Effects of revenue management on various efficiency dimensions of organization

\begin{tabular}{|l|c|c|c|c|c|c|c|c|c|c|}
\hline & \multicolumn{2}{|c|}{$\begin{array}{c}\text { Not } \\
\text { effective }\end{array}$} & \multicolumn{2}{c|}{$\begin{array}{c}\text { Slightly } \\
\text { effective }\end{array}$} & \multicolumn{2}{|c|}{$\begin{array}{c}\text { Moderately } \\
\text { effective }\end{array}$} & $\begin{array}{c}\text { More than } \\
\text { moderately } \\
\text { effective }\end{array}$ & \multicolumn{2}{|c|}{$\begin{array}{c}\text { Strongly } \\
\text { Effective }\end{array}$} \\
\hline & $\mathrm{n}$ & $\%$ & $\mathrm{n}$ & $\%$ & $\mathrm{n}$ & $\%$ & $\mathrm{n}$ & $\%$ & $\mathrm{n}$ & $\%$ \\
\hline Increases efficiency & & & & & & & 12 & 60 & 8 & 40 \\
\hline Increases profitability & & & & & & & 9 & 45 & 11 & 55 \\
\hline Decreases costs & & & 3 & 15 & 4 & 20 & 6 & 30 & 7 & 35 \\
\hline Enhances capacity usage & & & 1 & 5 & 3 & 15 & 8 & 40 & 8 & 40 \\
\hline
\end{tabular}




\section{CONCLUSIONS}

It is apparent from the findings that a big majority of the hotels subject to this research are aware of revenue management and its applications. Regardless of their star rankings or ownership status most of them are seeking increased revenue by means of revenue management applications. Findings revealed that three fourth of the participant are aware of revenue management issues and its applications on an accepTab. level of moderate or more. Amongst various types of information sources regarding to revenue management and its applications educational programs and printed materials such as books, journals and articles might be stated as the most referred ones followed by industrial applications gathered by industrial relations within the hotel business. With respect to willingness to learn and usage frequency level of revenue management applications it might be said that research results are overlapping and it is apparent that findings summarized in Tab. 4, 6 and 7 are proving each other. Approximately two thirds of the participants responded that they are utilizing revenue management tools with varying durations but the majority of this group falls into the "less than five years" group meaning that the revenue management is an emerging issue within Turkish hotel industry. With respect to the revenue management tools it is apparent that managers are using the tolls related to capacity management instead of the tolls related to pricing. Upselling might seem a tool related to pricing but instead it is the act of increasing the revenue with additional goods or services meaning that this is related to capacity or room allocation rather than pricing. Finally responses revealed that $40 \%$ of the participants who are aware of and utilize revenue management applications are employing software in order to enhance the revenue management process and attain better results. All the participants agreed that revenue management applications are effective on the indicators or outcomes such as efficiency, profitability, costs and capacity usage with varying degrees but it might be stated that affirmative results are generally on the levels of more than moderately or strongly.

\section{REFERENCES}

1. Buckhiester, B. (2011). Revenue Management as a Multi Disciplinary Business Process, The Journal of Hospitality Financial Management, 19 (1), 90-103.

2. Choi, T. Y. ve Cho, V. (2000). Towards a Knowledge Discovery Framework for Yield Management in the Hong Kong Hotel Industry, Hospitality Management, 19, 17-31.

3. Donaghy, K. ve McMahon-Beattie, U. (1997). Implementing Yield Management: Lessons from the Hotel Sector. International Journal of Contemporary Hospitality Management, 50-54.

4. Harris,F.H. ve Peacock, P.R. (1995). Yield management: Extending the concept in services marketing. Marketing Management.

5. Harris,F.H. vePinder, J.P. (1995). A revenue management approach to demand management and order booking in assemble-to-order manufacturing. Journal of Operations Management, 299-309.

6. Hacıoğlu, İ. (2011). Gelir Yönetimive Türkiye'deki Havayolu İşletmelerinde Gelir Yönetimi Üzerine Bir Uygulama. Yüksek Lisans Tezi. Edirne: Trakya Üniversitesi Sosyal Bilimler Enstitüsü.

7. Yeoman,I. ve Watson, S. (1997). Yield management: a human activity system. International Journal of Contemporary Hospitality Management, 9(2), 80-84. 
8. Ivanov, S. (2014). Hotel Revenue Management From Theory to Practice. Varna: Zangador Ltd.

9. Jauncey, S. Mitchell, I. veSlamet, P. (1995). The Meaning and Management of Yield in Hotels. International Journal of Contemporary Hospitality Management, 7 (4), 23-26.

10. Jerenz, A. (2008). Revenue Management and Survival Analysis in the Automobile Industry. Germany: GablerVerlag.

11. Kimes, S. (1989). The Basics of Yield Management. Cornell Hotel and Restaurant Administration Quarterly, 14-19.

12. Kimes, S. (2000). Revenue Management On the Links: Applying Yield Management to the Golf-Course Industry. Cornell Hotel and Restaurant Administration Quarterly, 120-127.

13. Lee-Ross, D. veJohns, N. (1997). Yield Management in Hospitality SMEs, International Journal of Contemporary Hospitality Management, 9 (2), 66-69.

14. Weatherford, L.B. ve Bodily, S. E. (1992). A taxonomy and research overview of perishable-asset revenue management: Yield management, overbooking and pricing. Operations Research, 40(5),831-844.

15. Li, W. (2011). Revenue Management in China's Hotel Industry: Barriers and Strategies. IPEDR, 144-147.

16. Yeoman, I. ve McMahon-Beattie, U. (2011). Revenue Management: A practical Pricing Perspective. Great Britain: Palgrave Macmillan.

17. Orkin, E. (1988). Boosting the Bottom Line With Yield Management. Cornell Hotel and Restaurant Quarterly, 28(4), 52-60.

18. Sfodera, F. (2006). The Spread of Yield Management Practices: The Need for Systematic Approaches. Almanya: Phsica-Verlag Heidelberg.

19. Talluri, K. veRyzin, G. (2004). Revenue Management under a General Discrete Choice Model of Consumer Behavior. Management Science, 15-33.

20. Tan, A. (2012). Otelcilik Sektöründe Gelir Yönetmi Uygulamaları. Yükseklisanstezi. Ankara: TOBB Ekonomive Teknoloji Üniversitesi Sosyal Bilimler Enstitüsü.

21. Unurlu, Ç. (2010). Otel İşletmelerinin Odalar Bölümünde Gelir Yönetimi: İstanbul'daki Beş Yıldızlı Otellerde Bir Uygulama. Yüksek Lisans Tezi. Edirne: Trakya Üniversitesi Sosyal Bilimler Enstitüsü.

22. Wirtz, J. ve Kimes, S. E. (2007). The Moderating Role of Familiarity in Fairness Perceptions of Revenue Management Pricing. Journal of Service Research, 9, (3), 229-240. 